\title{
Corporate Governance and its Impact on Firm Risk
}

\author{
Abdullah Alam* \\ Syed Zulfiqar Ali Shah

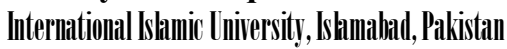

\begin{abstract}
The aim of this research is to explore the relationship of corporate governance with firm risk. This study establishes a link between corporate governance variables and firm risk for a sample of 106 Pakistani firms over a time of six years (20052010). Based on the estimation results, family control and bank control have negative impact on the firm risk whereas ownership structure and chairman/CEO duality posit positive relationship with risk. This provides a direction for firms to introduce more non-family control to the board of directors and not allow banks to have majority shareholding in their stocks. Also, directors should be asked to have a reasonable ownership in the stocks of the firm so that they can decide in the best interest of the firm and for the increase of their stock value. Chief executive should also hold the chair in order to have unity of command and a better decision-making influence.

Keywords: Corporate finance, Corporate Governance, firm risk, system GMM

JEL: G21, G32, G34
\end{abstract}

Studies on corporate governance have received considerable attention in the past decade or so due to the significant role of corporate governance in enhancing the firms' performance. Research has investigated the impact of various corporate governance measures have been on firm performance and firm value. Corporate governance measures like board structure, compensation structure and ownership structure are determined by one another, and by variables such as risk, cash flows, firms' size and regulations etc. These variables also strongly influence a firm' $s$ performance (Jensen and Meckling, 1976).

Firm risk ${ }^{1}$ has a role to play in firm performance ${ }^{2}$,

Manuscript received March 09, 2013; revised May 19, 2013; accepted June 05, 2013.

*Corresponding author Email: abdullah_alam@yahoo.com because firms that take more risk generally have higher (although volatile) returns. Due to their volatile nature, firm-specific risks hinder the firm's policy makers and planning department' $s$ ability to forecast and plan their cash flows and related activities, etc. These risks are generally related to the returns on the firm' $s$ stocks (Bloom and Milkovich, 1998). However, firm-specific risks are also directly related to the performance of the firm (Nguyen, 2011). Firms that engage in risky projects are expected to yield better returns that those which lack the appetite to take risks. However, excessive risk taking may prove to be fatal for a firm.

The relationship between corporate governance

1 Firm risk represents the firm's idiosyncratic (unpredictable) risk. It is a risk unique to a certain asset or company.

2 The results of activities of a firm over a given period of time. 


\section{Alam and Shah}

measures and firms' performance has been widely studied in corporate literature; although the evidence on this strand of literature has been mixed. The relationship between firm performance and governance may also be authenticated, theoretically, by considering agency theory ${ }^{3}$.

This mixed evidence suggests that the impact of corporate governance measures on firm performance may not be direct. It seems plausible that this relationship is mediated by the levels of firm's risk. For example, bank control, a corporate control measure, is expected to hamper the performance of a firm; since the bank would not allow the firm to indulge in projects/investments that involve taking high risks, thereby derailing the performance of the firm $^{4}$. Ownership structure may lead to the firm taking risky ventures since the directors now have their own stakes in the company and they would like to see their stakes get larger. Therefore, corporate governance has a strong role to play in the nature and intensity of risks taken by the firm, thereby impacting the performance of the firm.

A majority of the corporate governance studies have focused on developed countries. Although there has been significant development in research on the developing economies also over the last few years, comparatively fewer studies

3 Agency theory predicts that the conflict between managers and shareholders reduces the performance of the firm; therefore, a liaison between managers' and shareholders' interest is necessary. This signifies the link between governance and firms' performance.

${ }^{4}$ The example was based on the study of Weinstein and Yafeh (1998) who show that bank control hampers a firm's performance by limiting firm participation in risky ventures. focus on developing economies. Developing economies - the nature of their markets, economic uncertainty, the strength of their institutions, government interventions and the existence of individual biases - remain very different from developed economies. Corporate governance differs significantly in developed and developing countries (Rabelo and Vasconcelos, 2002). Therefore, the results of studies from developed markets might not be accurate in developing markets.

Furthermore, corporate governance research has mostly utilized Ordinary Least Square (OLS) and fixed/random effects estimation procedures. However, these studies also use explanatory variables that are not strictly exogenous, and use short time periods in their data panels.

Therefore, the published estimates may be biased (Wintoki, Linck, Netter, 2012) ${ }^{5}$. Wintoki et al. (2012) performed numerical simulations to show that the system Generalized Method of Moments (GMM) estimation used in this regard is powerful and unbiased, and shows different results from those of OLS and fixed effects estimation techniques. The system GMM estimator integrates the dynamic nature of corporate finance relationships and provides valid, yet powerful, instruments to control for ignored heterogeneity and simultaneity.

This study addresses these three issues simultaneously. This study investigates the role of corporate governance on firm risk, because of its significant relationship with firm performance. The

5 The study of Wintoki, Linck, Netter (2012) provides detailed arguments and related tests to prove the biasness of prior studies using static models. 
International Journal of Management, Economics and Social Sciences

empirical basis of this study is a developing market, Pakistan. Finally, the relationship between corporate governance variables and firm risk is explored using the dynamic panel GMM estimation technique instead of the OLS and fixed/random effects estimators. Therefore, this study serves as verification of Wintoki et al. (2012) regarding the bias of static models.

To the best of my knowledge, this is the first paper to investigate the link between corporate governance and firm risk using data of Pakistani firms. The study uses a data set that most global readers will find novel and unknown to them. Another contribution of this study is to incorporate a vast range of corporate governance variables in the analysis, including bank ownership ${ }^{6}$, family ownership $^{7}$, managerial ownership ${ }^{8}$, block holders $^{9}$, board independence ${ }^{10}$, board size ${ }^{11}$, chairman/CEO duality ${ }^{12}$ and audit committee independence $^{13}$. This study will provide policy makers and managers an understanding of the corporate governance practices and their relationship with firm' $s$ risk in the context of a developing economy. The reason for selecting

6 Bank control is positive when a bank has more than $50 \%$ shareholding in the firm.

7 Family control is considered positive when the founder or the founding family has influence over the firm policy and decision making.

8 The ratio of shares held by board of directors and the total number of shares.

9 The ratio of shares owned by top five shareholders and the total number of shares.

10 The ratio of non-executive directors to the total number of members of the board of directors.

11 It is represented by the total number of members of the board.

12 A dummy having value as 1 if the chairman or the chief executive officer is the same person and 0 otherwise.

13 The ratio between non-executive directors in audit committee and the total number of directors in audit committee these eight variables, inter alia, was their relationship pointed out in prior literature on the topic; as one of our aims was to compare our results of system GMM modeling with prior research utilizing OLS estimation. Ease of data availability was also one of the factors that led us to consider these specific eight variables.

\section{LITERATURE REVIEW}

Better corporate governance leads to better operating performance (Drobetz, Schillhofer and Zimmermann, 2003). Corporate governance has a major role to play in the performance of firms. This role may be in relation to its decisionmaking metrics or its ability to indulge in risky projects to increase the chances of superior returns. Aman and Nguyen (2008) point out the opposing nature of the relationship between corporate governance and firm performance. Aman and Nguyen (2008) create a governance index for Japanese firms which reflected board characteristics, ownership structure, quality of disclosure and respect for investors' interests. The analysis covering the period 2000 - 2005 shows that stock prices reflect the risk associated with corporate governance in accordance with the market efficiency. Firms with lower governance ratings are observed to have produced higher returns because of more exposure to risk.

The empirical literature on the relationship between corporate governance and firm risk is not very well-developed, although there is vast literature available on the impact of corporate governance on firm's value (and performance). Since it is known that risk is directly related to 
returns, therefore, firm risk has a strong, although indirect, link to the performance of the firm.

Table 1 (Panel A) presents a summary of studies that have explicitly discussed the relationship between corporate governance and firm risk, whereas Table 1 (Panel B) focuses on those studies implicitly related to this study by researching the impact of corporate governance on firm performance (or firm value). Table 1 (Panel C) refers to some of the studies carried out in Pakistan on the impact of corporate governance on firm performance. Table 1 (see Appendix-l) also shows the type of estimator used in each study.

\section{Family Ownership and Firm Risk}

Nguyen (2011) studies the impact of corporate governance (through family control, bank control and ownership concentration) on risk taking of Japanese firms. For a sample of 1252 nonfinancial firms covering 27 industry sectors, Nguyen concludes that family control and ownership concentration are positively related to the idiosyncratic risk, whereas bank control reduces operational risk. Relating the firms' corporate governance structure to its risk-taking approaches, firms with concentrated ownership perform well. Saito (2008) also studies the impact of corporate governance (through family control) on the performance of Japanese firms.

Family firms ${ }^{14}$ managed by founders are traded at premium. The performance of family firms owned and managed by founder' $s$ descendents is below non-family firms. On the other hand, the

\footnotetext{
${ }^{14}$ Family firms are those firms where the founder or the founding family has influence over the firm policy and decision making.
}

performance of family firms owned or managed by founder' $s$ descendents is higher than nonfamily firms. Anderson and Reeb (2003) show that U.S family firms have higher profitability and valuation than their non-family counterparts. For a sample of 1672 non-financial firms from 13 Western European countries, Maury (2006) finds that family control is linked with 7 percent higher valuations and 16 percent higher profitability in comparison with firms controlled by non-family owners. It can therefore be concluded that firms managed by family members show better performance. The underlying reason behind this better performance can be the powerful decisionmaking authority in the hands of the family running the business. Thus, risky projects may also get accepted and in turn higher performance is achieved. Because firm performance and firm risk are correlated, family ownership may lead to higher risk-taking by family firms. These observations lead to the first hypothesis.

$\mathrm{H}_{1}$ : Family Ownership is positively related to firm risk.

\section{Bank Ownership and Firm Risk}

Another corporate governance measure significant in this regard is the bank control or bank ownership. Banks are expected to have low risk-taking preferences and are most likely to avoid risky ventures. Morck, Nakamura and Shivdasani (2000) have reported a negative association between bank ownership of Japanese firms and its value. On the same line, studies like Weinstein and Yafeh (1998) and Nguyen (2011), using Japanese firm-level data, show negative association between bank control and firm risk. The argument that returns volatility (risk) is 
International Journal of Management, Economics and Social Sciences

positively related to firm' $s$ performance can also be validated from the analysis of Weinstein and Yafeh (1998) who show that banks have lower earnings volatility and poor operating performance. Therefore, it is expected that higher bank ownership would lead to lesser firm risk.

$\mathrm{H}_{2}$ : Bank Ownership is negatively related to firm risk.

\section{Ownership Structure and Firm Risk}

Managerial ownership plays a significant role in firm's risk-taking. Lesser ownership in this regard may hold back the managers to indulge in risky projects. In case the executives of a firm also own stocks of the firm, they will prefer actions that are in the best interest of all the investors (Singh and Harianto, 1989). Hirshleifer and Thakor (1992) indicate that some managers cater for their careers and avoid risk-taking; sometimes even those risks are avoided that could have potentially increased the value of the firm. Empirical evidence in this regard is divided where studies like Wright, Ferris, Sarin and Awasthi (1996) estimate a negative relation between managerial ownership and firm risk. On the same lines Shah et al. (2011) and Wahla, Shah and Hussain (2012) also indicate a negative relationship between managerial ownership (ownership structure) and firm performance in Pakistani context. On the contrary, managerial ownership is found to have positive relationship with firm risk in the analysis of Hutchinson (2001) and with firm value in the studies of Morck et al. (2000) and Chen, Guo and Mande (2003). In their studies on Pakistani sample of 60 firms over the time period of 2003-2008, Javid and labal (2008) also estimate a positive relationship between managerial shareholding and firm performance. On the whole, this study is motivated of the positive nature of the relationship between ownership structure and firm risk considering that there is an incentive for managers to indulge in risky ventures.

$\mathrm{H}_{3}$ : Managerial Ownership is positively related to firm risk.

Block Holders (Ownership Concentration) and Firm Risk

Distributed ownership reduces the interest of individual stakeholders in the performance of the firm. Concentrated ownership, on the other hand, raises the interest of the stakeholders to monitor the progress of the firm and thereby contributing towards its better performance. Claessens and Djankov (1999) find that enhanced ownership concentration has a positive impact on the profitability and labor productivity of Czech firms. Similar positive associations of ownership concentration have also been presented by McConnell and Servaes (1990) and Nguyen (2011) with corporate performance and firm risk respectively. In the Pakistani context, Javid and labal (2008) also estimate a positive relationship between ownership concentration and firm performance.

$\mathrm{H}_{4}$ : Block holders have positive relation with firm risk.

\section{Board Independence and Firm Risk}

Structuring of a firm' $s$ board of directors also plays a crucial role in reducing the agency costs (Hutchinson and Gul, 2003). Therefore, the role of the executive board' s structure is also crucial for the firm's value. Non-executive directors on the board of directors, acting on the part of 


\section{Alam and Shah}

external shareholders, are generally expected to monitor firm' s strategy and decision-making in this regard (Fama, 1980). For a sample of 91 Pakistani firms, Khan and Awan (2012) find positive association between board composition (independence) and firm performance. Similar positive relationship has also been estimated by Ibrahim, Rehman and Raoof (2010) and Yasser, Entebang and Mansor (2011) for a sample of 10 and 30 Pakistani firms respectively. On the contrary, studies like Bhagat and Black (2002) and Bhagat and Bolton (2008) have found a negative relationship between board independence and firm performance. In short, there has been no consensus on the nature of relationship between board independence and firm' s performance. However, this study is motivated that the presence of more nonexecutive directors may obstruct the indulgence of the firm in riskier projects as they are concerned with the volatility of the returns in such scenarios. Also the chief executive officer (CEO) may not feel comfortable to discuss all the strategic matters with the non-executive directors, thereby creating a gap between the firm's decisions and the involvement of its independent board members. Therefore, a negative association may be expected in this regard.

$\mathrm{H}_{5}$ : $\quad$ Board independence is negatively related to firm risk.

\section{Board Size and Firm Risk}

Board size is also relevant to the firm performance as more the number of directors in the board are, better will be the decision-making, as no one person will be able to make decisions on his own. Belkhir (2009) and KyereboahColeman and Biepke (2006) have found a positive relationship between board size and firm performance. Haleblian and Finkelstein (1993) advocate larger boards because of the enhanced collective information that they may possess in terms of markets and strategies. Dar, Naseem, Rehman and Niazi (2011), for a Pakistani sample of 12 firms over the period 2004-2010, estimate a positive relationship between board size and firm performance. Similar positive association has also been reported by Yasser et al. (2011) considering Pakistani firms.

However, research has also specified opposite relationship between board size and firm performance. Yermack (1996) estimate a negative relationship between board size and firm performance for a sample of 491 U.S firms over the time period of 1984 - 1991. Similar negative association has been found by Eisenberg, Sundgren and Wells (1998) for Finland sample. Some of the other studies to establish negative relationship in this regard include Conyon and Peck (1998), Lasfer (2004), Cheng, Evans and Nagarajan (2008) and Guest (2009).

Because of the risky environment facing the Pakistani firms, it is expected that there may exist a positive relationship between board size and firm risk as collective information of the members of the board will be useful and may prevail in such environments.

$\mathrm{H}_{6}$ : Board size is positively related to firm risk.

\section{Audit Committee Independence and Firm Risk}

An independent audit committee may force the decision-makers to indulge in limited risk-taking projects as failure of a volatile one will raise 
International Journal of Management, Economics and Social Sciences

uncertainty among the shareholders. Mak and Kusnadi (2005) do not find any significant relationship between audit committee independence and firm value for a sample of Singaporean and Malaysian firms. Similar results have also been estimated by Hsu (2008). For a sample of Canadian firms over the 1993-1997 time period, Erickson, Park, Reising and Shin (2005) find a positive relationship between audit committee independence and firm performance. In the Pakistani scenario, Dar et al. (2011) have found a negative relationship between audit committee independence and firm performance. This study is motivated of the negative relationship between an independent audit committee and firm risk.

$\mathrm{H}_{7}$ : Audit committee independence is negatively related to firm risk.

\section{Chairman/CEO Duality and Firm Risk}

Considering agency theory, CEO duality may hamper the performance of the firm as the control and monitoring on chief executive officer is compromised. The chief executive officer, in his rights as chairman of the firm, may select those directors alongside him in the board who are either family members or are less likely to differ in opinion and decision-making (Westphal and Zajac, 1995). On the contrary, stewardship theory may relate to better performance since there is unified command and decision-making becomes focused. This will help reduce the confusion among managers and other stakeholders about the actual decision-maker and may help in an effective decision-making (Finkelstein and D' Aveni, 1994). Based on the motivation achieved from the stewardship theory, this study expects a positive relationship of CEO duality and firm risk.

$\mathrm{H}_{8}$ : Chairman/CEO Duality is positively related to firm risk.

\section{Firm Risk Modeling}

\section{- Measuring Idiosyncratic (Firm) Risk}

Firm risk is calculated using Fama and French (1993) three factor model in line with the methodology of Saito (2008) and Nguyen (2011).

The three factor model is an extension of the single factor CAPM model where apart from the traditional beta; it utilizes two other factors in the form of value and size factors. Fama and French (1993) three factor model includes monthly excess return on market index $\left(R_{M}-R_{f}\right)$, size $(S M B)$ factor and book-to-market (HML) factor. Fama and French 3-factor model can be represented as:

$\mathrm{E}\left(\mathrm{R}_{i}\right)=\mathrm{R}_{f}+\beta_{1} \mathrm{MKT}+\beta_{2} \mathrm{SMB}+\beta_{3} \mathrm{HML} \cdots \cdot(1)$

where $E\left(R_{i}\right)$ represents the expected stock returns on the stock $i$, SMB represents the size premium and HML represents the value premium.

Stocks are arranged in descending order according to their market capitalization and then the sample is divided into two equal portfolios on either side of the median. The portfolio having market capitalization more than the median is named as 'Big' whereas the other one is named as ' Small'. Now, these two portfolios are each further sub-divided into three portfolios (upper 30 percent, middle 40 percent and lower 30 percent) based on their book-to-market ratio arranged in ascending order. The 'small' and ' big' portfolios are subsequently named as S/L (small and lower 30 percent), S/M (small and 


\section{Alam and Shah}

middle 40 percent), $\mathrm{S} / \mathrm{H}$ (small and upper 30 percent), B/L (big and lower 30 percent), B/M (big and middle 40 percent) and $\mathrm{B} / \mathrm{H}$ (big and upper 30 percent).

The three Fama and French factors are then calculated as:

$S M B=\frac{\left(\frac{S}{H}-\frac{B}{H}\right)+\left(\frac{S}{M}-\frac{B}{M}\right)+\left(\frac{S}{L}-\frac{B}{L}\right)}{3}$

$H M L=\frac{\left(\frac{S}{H}-\frac{S}{L}\right)+\left(\frac{B}{H}-\frac{B}{L}\right)}{2}$

$M K T=R_{M}-R_{f} \quad$ where, $\quad R_{M}=\frac{P_{t}}{P_{t-1}}$

$R_{M}$ represents the market return for month $t . P_{t}$ and $P_{t-1}$ are closing values of KSE-100 Index for month $t$ and $t-1$ respectively. $R_{f}$ is risk-free rate for which monthly $T$-bill rate has been used as proxy.

After estimating equation (1) for each stock year dataset (a total of 636 regressions are run for 106 stocks and 6 years) in the sample, the standard deviation of the regression residual determined the firm-specific or idiosyncratic risk.

\section{- Dynamic Modeling of Firm Risk}

Following equation represents a dynamic model for the impact of ownership and board characteristics on firm risk:

$f\left(y_{x t} \mid y_{x t-1}, \ldots \ldots \ldots \ldots y_{x t-k}, O_{x t}, B_{x t}, C_{x t}, \lambda_{x}\right)=\alpha+\sum_{m} \rho_{m} y_{x t-m}+\beta_{x} O_{x t}+\gamma_{x} B_{x t}+\chi_{y} C_{x t}+\lambda_{x}$ $\cdots \cdots \cdots$ (2)

where, $\mathrm{m}=1,2, \cdots \cdots, \mathrm{k}$ and $O, B, C$ and $y$ represent ownership, board characteristics, firm characteristics and risk respectively. $\lambda$ represents a firm effect that is unobserved whereas $\beta_{x}$ and $\gamma_{x}$ measure the impact of ownership variables and board characteristics on firm risk. Inclusion of lagged dependent variables indicates the fact that past values of the variables also have an impact on the current values.

Cross-sectional estimation of the model in equation (2) leads to the following equation:

$y_{x t}=\alpha+\sum_{m} \rho_{m} y_{x t-m}+\beta O_{x t}+\gamma B_{x t}+\chi C_{x t}+\lambda_{x}+\varepsilon_{x t}$

where, $\mathrm{m}=1,2, \cdots \cdots ., k$ and $\varepsilon_{x t}$ is the random error term. $\beta$ and $\gamma$ measure the average impact of ownership variables and board characteristics on firm risk.

\section{- Dynamic Panel GMM Estimation}

In order to attain unbiased and consistent estimates, dynamic generalized method of moments (GMM) panel estimation technique initiated by Holtz-Eakin, Newey and Rosen (1988) and Arellano and Bond (1991) has been used in this research. This estimation methodology is preferred because it removes chances of any bias that may arise from ignoring dynamic endogeneity. Also it presents powerful yet reliable instruments to account for simultaneity and eliminating unobservable heterogeneity. It is a two-step procedure where the equation (3) is first written in first-differenced form as:

$y_{x t}=\alpha+\rho_{m} \sum_{m} \Delta y_{x t-m}+\beta \Delta O_{x t}+\gamma \Delta B_{x t}+\chi \Delta C_{x t}+\varepsilon_{x t}$ where $p>0$

(4)

After first differencing, equation (4) is estimated using GMM technique by using lagged values of the explanatory variables as instruments for present values of the variables ${ }^{15}$.

However, there are three potential problems with this procedure as identified by Wintoki et al. (2012). First, there is a power reduction in the

${ }^{15}$ Historical values of firm risk, ownership, board characteristics and other firm characteristics are used as instruments for current changes in them. 
International Journal of Management, Economics and Social Sciences

tests after differencing due to signal to noise ratio when the conceptual model is in levels (Beck, Levine and Loayza, 2000). Secondly, variables in level form can be weak instruments for the differenced equations (Arellano and Bond, 1995). Thirdly, the effect of measurements errors on the dependent variables may worsen after firstdifferencing (Griliches and Hausman, 1986).

System GMM estimator ${ }^{16}$, using the firstdifferenced variables as instruments for the level equations in a system of equations including equations in levels and difference form, may help in addressing the above shortcomings. The system GMM estimation equation is as follow:

$\left[\begin{array}{c}y_{x t} \\ \Delta y_{x t}\end{array}\right]=\alpha+\rho\left[\begin{array}{c}y_{x t-m} \\ \Delta y_{x t-m}\end{array}\right]+\beta\left[\begin{array}{c}O_{x t} \\ \Delta O_{x t}\end{array}\right]+\gamma\left[\begin{array}{c}B_{x t} \\ \Delta B_{x t}\end{array}\right]+\chi\left[\begin{array}{c}C_{x t} \\ \Delta C_{x t}\end{array}\right]+\varepsilon_{x t}$ ........... (5)

\section{METHODOLOGY}

Corporate governance data for the 106 firms used in the study was collected mainly from individual firm' s annual reports. The time period under study was 2005 - 2010. This time period was selected based on the ease of availability of data for the variables.

Summary statistics for the variables used in this study are reported in Table 2 below.

The sample of 106 firms was selected keeping the mind the following criteria as adopted by Nguyen (2011) and Wahla et al. (2012):

- Financial institutions (banks, securities, insurance companies and financial serviceproviding companies) were excluded due to their particular performance and risk-taking metrics.

- Firms with negative equity were also excluded due to potentially excessive risk-taking behavior.

Instances with missing ownership and board characteristics information or incomplete financial data were also excluded from the sample. After removing the financial institutions from the complete sample, 447 companies survived out of the total 667 companies listed on the Karachi

\begin{tabular}{ccccc}
\hline Category & Variable & Mean/\% & Median & Std. Dev. \\
\hline Risk & Firm Risk & 0.12 & 0.11 & 0.05 \\
\hline \multirow{2}{*}{ Ownership } & Managerial ownership & $18.83 \%$ & 6.11 & 24.82 \\
\cline { 2 - 5 } & Block holders & $66.68 \%$ & 68.5 & 18.5 \\
\hline \multirow{3}{*}{ Board Characteristics } & Board independence & 0.66 & 0.71 & 0.22 \\
\cline { 2 - 5 } & Budit committee independence & 0.78 & 0.67 & 0.23 \\
\cline { 2 - 5 } & Firm size & 22.03 & 21.97 & 1.61 \\
\cline { 2 - 5 } & Firm leverage & $42.85 \%$ & 35.32 & 35.56 \\
\cline { 2 - 5 } Control Variables & Growth opportunities & 0.98 & 0.66 & 1.05 \\
\cline { 2 - 5 } & Firm profitability & $11.79 \%$ & 9.37 & 13.24 \\
\cline { 2 - 5 } & Capital intensity & $40.68 \%$ & 39.51 & 23.65 \\
\hline
\end{tabular}

Note: Statistics for dummy variables have not been presented in the table.

Table 2. Summary Statisics

${ }^{16}$ With System GMM estimation, efficient estimates are obtained and dynamic endogeneity, unobserved heterogeneity and simultaneity are also controlled. It is also assumed that there is no serial correlation in the error term $\varepsilon$.
Stock Exchange (KSE). Out of the available sectors, 'Personal Goods' sector had majority of the representation i.e., $43 \%$ of the total 
number of companies in the reduced sample of 447 companies. In order to minimize the impact of sector-specific biases/metrics on our estimation, each sector was given appropriate representation in the data (no single sector had more than $15 \%$ representation in the sample). Accounting for the firms with negative equity and/or instances of missing or incomplete data, the final sample was reduced to 106 firms. Table 3 presents the participation of each sector in the reduced and the selected sample for this study. characteristics variables. Ownership variables include family ownership, bank ownership (control dummies for family and bank), managerial ownership and block holders. Board characteristics include board independence, board size, chairman/CEO duality and audit committee independence. Table 4 provides a description of governance variables used in the study.

Control variables ${ }^{17}$ include firm's size, leverage, growth opportunities, profitability and capital

\begin{tabular}{|c|c|c|c|c|c|}
\hline $\begin{array}{c}\text { Sector } \\
\text { Number }\end{array}$ & Sector Name & $\begin{array}{c}\text { Total } \\
\text { Number of } \\
\text { Companies } \\
\end{array}$ & $\begin{array}{c}\text { \%age in Total } \\
\text { Available } \\
\text { Sample } \\
\end{array}$ & $\begin{array}{c}\text { Selected } \\
\text { Number of } \\
\text { Companies } \\
\end{array}$ & $\begin{array}{c}\text { \%oage in } \\
\text { Selected } \\
\text { Sample } \\
\end{array}$ \\
\hline 1 & Oil and Gas & 12 & $2.68 \%$ & 7 & $6.60 \%$ \\
\hline 2 & Chemicals & 33 & $7.38 \%$ & 14 & $13.21 \%$ \\
\hline 3 & Forestry and Paper & 4 & $0.89 \%$ & 2 & $1.89 \%$ \\
\hline 4 & Industrial Metals and Mining & 8 & $1.79 \%$ & 2 & $1.89 \%$ \\
\hline 5 & Construction and Materials & 38 & $8.50 \%$ & 12 & $11.32 \%$ \\
\hline 6 & General Industries & 13 & $2.91 \%$ & 6 & $5.66 \%$ \\
\hline 7 & Electronic and Electrical Equipment & 3 & $0.67 \%$ & 1 & $0.94 \%$ \\
\hline 8 & Industrial Engineering & 11 & $2.46 \%$ & 5 & $4.72 \%$ \\
\hline 9 & Automobile and Parts & 16 & $3.58 \%$ & 7 & $6.60 \%$ \\
\hline 10 & Beverages & 4 & $0.89 \%$ & 1 & $0.94 \%$ \\
\hline 11 & Food Producers & 58 & $12.98 \%$ & 15 & $14.15 \%$ \\
\hline 12 & Household Goods & 13 & $2.91 \%$ & 2 & $1.89 \%$ \\
\hline 13 & Leisure Goods & 1 & $0.22 \%$ & 1 & $0.94 \%$ \\
\hline 14 & Personal Goods & 191 & $42.73 \%$ & 13 & $12.26 \%$ \\
\hline 15 & Tobacco & 3 & $0.67 \%$ & 1 & $0.94 \%$ \\
\hline 16 & Health Care Equipment and Services & 2 & $0.45 \%$ & 1 & $0.94 \%$ \\
\hline 17 & Pharma and Bio Tech & 9 & $2.01 \%$ & 5 & $4.72 \%$ \\
\hline 18 & Travel and Leisure & 5 & $1.12 \%$ & 2 & $1.89 \%$ \\
\hline 19 & Fixed Line Telecommunication & 5 & $1.12 \%$ & 3 & $2.83 \%$ \\
\hline 20 & Electricity & 16 & $3.58 \%$ & 5 & $4.72 \%$ \\
\hline \multirow[t]{2}{*}{21} & Gas Water and Multiutilities & 2 & $0.45 \%$ & 1 & $0.94 \%$ \\
\hline & Total & 447 & & 106 & \\
\hline
\end{tabular}

Table 3. Sector-wise Distribution of Selected Firms

Data for control variables was extracted from State Bank of Pakistan (SBP) Financial Statements Analysis (FSA) of Non-Financial Companies (2005-2010). Stock prices and market capitalization data was taken from the Business Recorder website.

Governance variables used in this study can be categorized into ownership variables and board intensity. These are included in the regression as they are considered to affect either the firm' $s$ risk or the measurement of that risk.

- Size is the natural logarithm of the firm' s total assets.

17 These variables had strong support in prior literature. Similar variables have been used by Nguyen (2011). 
International Journal of Management, Economics and Social Sciences

- Leverage is the ratio of book equity to total assets.

- Growth opportunities are proxied by book to market ratio.

- Profitability is represented by return on assets (ROA) which is the ratio of operating profits to total assets.

- Capital intensity is represented by the ratio of fixed to total assets. share of directors in the stocks of the firm relates to higher risk-taking due to the incentive of higher returns on their own stocks also. Chairman/CEO duality was also positively related to firm risk indicating the significance of having the same person as the chairman and the chief executive officer. All the control variables except firm leverage significantly correlated with firm risk.

\begin{tabular}{|c|c|c|}
\hline Category & Variable & Definition \\
\hline \multirow{4}{*}{ Ownership } & Family ownership & $\begin{array}{l}\text { A dummy having value } 1 \text { for a family firm (firms where the } \\
\text { founder or the founding family has influence over the firm policy } \\
\text { and decision making.) and } 0 \text { otherwise. }\end{array}$ \\
\hline & Bank ownership & $\begin{array}{l}\text { A dummy having value } 1 \text { for a firm having a bank as its majority } \\
\text { shareholder (more than } 50 \% \text { shareholding) and } 0 \text { otherwise. }\end{array}$ \\
\hline & Managerial ownership & $\begin{array}{l}\text { It is the ratio of shares held by board of directors and the total } \\
\text { number of shares. }\end{array}$ \\
\hline & Block holders & $\begin{array}{l}\text { It is the ratio of shares owned by top five shareholders and the } \\
\text { total number of shares. }\end{array}$ \\
\hline \multirow{4}{*}{$\begin{array}{c}\text { Board } \\
\text { Characteristics }\end{array}$} & Board independence & $\begin{array}{l}\text { It is the ratio of non-executive directors (external board } \\
\text { members) to the total number of members of the board of } \\
\text { directors. }\end{array}$ \\
\hline & Board size & It is represented by the total number of members of the board. \\
\hline & Chairman/CEO duality & $\begin{array}{l}\text { A dummy having value as } 1 \text { if the chairman and the chief } \\
\text { executive officer is the same person and } 0 \text { otherwise. }\end{array}$ \\
\hline & $\begin{array}{l}\text { Audit committee } \\
\text { independence }\end{array}$ & $\begin{array}{l}\text { It is the ratio between non-executive directors in audit committee } \\
\text { and the total number of directors in audit committee. }\end{array}$ \\
\hline
\end{tabular}

Table 4. Description of Governance Variables

\section{RESULTS AND DISCUSSION}

\section{Correlation Analysis}

Table 5 (see Appendix-II) corresponds to the correlation analysis of the variables used in the study. Family ownership is positive related to firm risk as is expected in our hypothesis 1. This indicates that more family ownership should induce higher risk-taking on the part of the decision-makers. Bank ownership has a negative relationship with firm risk. This strengthens our hypothesis 2 which expects a negative association between the two variables. Managerial ownership is also significantly correlated with firm risk indicating that higher

\section{Number of Significant Lags for Estimation}

It is well-known that the appropriate number of lags of the dependent variable has to be incorporated in the dynamic models so that all the information from the past is captured. Failing to include all the significant lags will result in an omitted variable bias mis-specifying the equation (3). Also, all older lags can be used as valid instruments since they are argued to be exogenous with respect to the residuals of the present. For checking the significant lags required for our estimation, three ${ }^{18}$ lags of the dependent

18 The estimation was also conducted for more than 3 lags but insignificant estimates were achieved for higher lags. 


\section{Alam and Shah}

variable are included in the regression of current firm risk on the lags of past firm risk. Control variables are also used in the regression. Table 6 presents the results of the estimation. and firm risk by including the past performances and the fixed effects so that dynamic endogeneity and unobservable heterogeneity can be controlled.

\begin{tabular}{ccc}
\hline Dependent Variable: Firm Risk & All 3 Lags Included & First Lag Ignored \\
\hline Risk $(t-1)$ & $\mathbf{0 . 9 8 1}(\mathbf{2 9 . 0 9})^{* * * *}$ & \\
\hline Risk $(t-2)$ & $-0.032(0.51)$ & $\mathbf{0 . 9 1}(\mathbf{1 3 . 2 1})^{* * * *}$ \\
\hline Risk $(t-3)$ & $-\mathbf{0 . 1 0 2}(\mathbf{0 . 0 9})^{*}$ & $-\mathbf{0 . 2 2}(-\mathbf{2 . 4 1})^{* * *}$ \\
\hline Firm Size & $-0.002(-1.23)$ & $-\mathbf{0 . 0 0 3}(-\mathbf{1 . 7 7})^{* *}$ \\
\hline Firm Leverage & $0.0001(1.00)$ & $\mathbf{0 . 0 0 0 2}(\mathbf{2 . 4 0})^{\text {*** }}$ \\
\hline Growth Opportunities & $\mathbf{0 . 0 0 3}(\mathbf{2 . 1 0})^{* *}$ & $\mathbf{0 . 0 0 4}(\mathbf{2 . 5 0})^{* * *}$ \\
\hline Firm Profitability & $-0.0002(-1.26)$ & $-0.003(-1.44)$ \\
\hline Capital Intensity & $0.0001(0.89)$ & $0.0002(1.34)$ \\
\hline$R^{2}$ & 0.84 & 0.54 \\
\hline
\end{tabular}

Notes:

- $\quad t$-statistics are reported in parentheses.

$\stackrel{* * * * * *,}{*}$ represent significance at $1 \%, 5 \%$ and $10 \%$ levels respectively.

Table 6. Number of Significant Lags for Estimation

In the first column of the Table 6 , using all the 3 lags of risk, it can be observed that the first lag is highly significant with the second lag being insignificant. This ensures that the first lag is enough to capture the dynamic nature of the firm risk and corporate governance relationship. In the second column of Table 6, the most recent (first lag) is dropped and the two older lags are used. Now, the older lags also become significant which indicates that although the older lags include related information, that information is absorbed by the most recent lag.

Dynamic Modeling of the Impact of Corporate Governance on Firm Risk

Using system GMM modeling allows estimating the relationship between corporate governance
The results of Table 7 indicate the relevance of the independent variables in estimating the firm risk. Bank ownership $(-0.0096, t=-1.81)$ and family ownership $(-0.0312, t=-2.01)$ are both significant and negative rejecting hypothesis 1 and accepting hypothesis 2 of the study. These results show that the firms that have banks as strong shareholders are less risk-taking in general. The negative and significant nature of the bank ownership variable is in line with the findings of Weinstein and Yafeh (1998) and Nguyen (2011) for Japanese firms. On the contrary, the negative coefficient of family ownership contradicts the findings of Nguyen (2011) who indicated a positive relationship between family ownership and firm risk. The 
International Journal of Management, Economics and Social Sciences

reason for this contradictory result may be the results of Hutchinson (2001). This indicates that if nature of the two markets, Japan and Pakistan, members of the board of directors also have where the latter is more vulnerable and therefore reasonable shareholding in a firm, more riskthe firms that have family influence over taking behavior should be expected. The reason decision-making do not indulge in excessive risk- for such behavior is that now they would taking due to lesser probability of higher returns. also have stronger incentives to indulge in risky

\begin{tabular}{|c|c|}
\hline Dependent Variable: Firm Risk & System GMM \\
\hline Bank Ownership & $-0.0096(-1.81)^{*}$ \\
\hline Family Ownership & $-0.0312(-2.01)^{* * *}$ \\
\hline Managerial Ownership & $0.002(4.62)^{* * *}$ \\
\hline Block holders & $0.0002(1.46)$ \\
\hline Board Independence & $-0.0084(-0.59)$ \\
\hline Board Size & $0.031(1.49)$ \\
\hline Chairman/CEO Duality & $0.017(1.99)^{* *}$ \\
\hline Audit Committee Independence & $-0.0167(-1.46)$ \\
\hline Firm Size & $0.0074(3.46)^{* * *}$ \\
\hline Firm Leverage & $0.0003(8.34)^{* * *}$ \\
\hline Growth Opportunities & $0.0049(4.34)^{* * *}$ \\
\hline Firm Profitability & $0.0002(3.02)^{* * *}$ \\
\hline Capital Intensity & $0.0002(2.15)^{* *}$ \\
\hline Firm Risk $(t-1)$ & $0.0414(1.06)$ \\
\hline Difference-in-Hansen test of exogeneity ( $p$-value) & $(0.61)$ \\
\hline$A R(1)$ test ( $p$-value) & $(0.29)$ \\
\hline$A R(2)$ test ( $p$-value) & $(0.25)$ \\
\hline
\end{tabular}

Notes:

- Difference-in-Hansen test of exogeneity is under the null that exogenous instruments are used for level equations.

- $\quad A R(1)$ and $A R(2)$ are $1^{\text {st }}$ and $2^{\text {nd }}$ order serial correlation (in the first differenced residuals) tests. The null hypothesis is no correlation.

- $t$-statistics are reported in parentheses.

$\stackrel{* * * * *}{*}$ represent significance at $1 \%, 5 \%$ and $10 \%$ levels respectively.

Table 7. Impact of Corporate Governance on Firm Risk (Dynamic Model)

Managerial ownership is seen to impact firm ventures. Positive association of managerial risk by showing a significant and positive ownership with firm risk is contradicting with the coefficient (0.002, $t=4.62)$ supporting the results of Shah et al. (2011) and Wahla et al. 
(2012) for Pakistani sample. The reason for this contradicting result may be the biased nature of the estimation techniques used by these researchers.

CEO/Chairman duality is also positively (and significantly) related to firm risk $(0.017, t=1.99)$ supporting hypothesis 8 of the study. The likelihood of Chairman and CEO being the same person also increase the risk-taking behavior of firms as it is only one person who is now responsible for highest level decision-making.

Based on the estimation results in Table 7 , this study did not find any significant relationship between block holders, board independence, board size and audit committee independence for their relationship with firm risk. This indicated that there was no empirical support for hypotheses 4, 5,6 and 7 .

As expected, all the control variables show significant coefficients as their relationship with firm risk was backed up by strong empirical and theoretical grounds. The most important of these is the relationship of firm profitability (measured by $\mathrm{ROA}^{19}$ ) with firm risk. As, much of this study' $s$ motivation was based on the intuition that firm performance (profitability) is positively related to firm risk; the positive coefficient (0.0002, $t=3.02)$ indicated strong support for this relationship.

$A R(1)$ and $A R(2)$ tests of serial correlation, having the hypotheses of no serial correlation, indicate that there is no serial correlation in first or second differences. Since, this study uses only

19 ROA has been in many prior studies as a proxy for firm performance. one lag of firm risk as an instrument, the system may not be over-identified in this case.

\section{Static Modeling of the Impact of Corporate Governance on Firm Risk}

Based on the argument of Wintoki et al. (2012)

related to the biasness of static models used for

the estimation of governance-performance

relationship, this study also employed static panel data techniques (Pooled OLS and Random effects estimation ${ }^{20}$ ) to see if the argument is supported by the present study' s data.

Table 8 (See Appendix-III) shows support for the argument of Wintoki et al. (2012) as the results show major differences in coefficient estimates (with their related significance) compared to those of Table 7 for the dynamic model. Although bank ownership and Chairman/CEO duality were significant in both of the static estimations, family ownership and managerial ownership did not produce significant coefficients as is the case in Table 7. Block holders (RE estimation) and board independence (OLS estimation) are significantly related to firm risk producing negative and positive associations respectively. Also majority of the control variables, which have empirical and theoretical support for their relationship with firm risk/performance, did not yield significant coefficients in the case of static estimations.

\section{CONCLUSION}

The impact of corporate governance on firm performance and firm risk has been widely discussed, empirically and theoretically in prior studies; although the latter needs more research 
International Journal of Management, Economics and Social Sciences

efforts. Based on the study results of Wintoki et al. (2012) that endogeneity concerns hamper the real estimates of the relationship between firm performance and corporate governance, prior studies considering static estimation models may present biased and unreliable estimates.

The significance of this research is two-fold. First of all, the relationship between corporate governance (ownership variables and board characteristics) and firm risk is explored in this study. For a sample of 106 Pakistani firms over a time period of 2005 - 2010, system GMM estimates indicate that family ownership and bank ownership are negatively related to firm risk. Also, a positive relationship is established for the association of managerial ownership and Chairman/CEO duality with firm risk.

Secondly, this study provides some argument on the nature of the developing and the developed markets. It is expected that the metrics of the markets in developed and developing economies vary. Therefore, a separate code of corporate governance may be established and applied in developing markets that is representative of the nature of these markets. The contrasting nature of the two markets can be envisioned from the relationship of family ownership and firm risk where studies based on Japanese, US and Western Europe samples estimated a unanimous positive association between the two variables. But in case of our sample for a developing country, a negative relationship was found specifically due to the

20 Random effects model was used on the basis of the result of Hausman's Test. contrasting nature of the developed and developing markets.

\section{IMPLICATIONS}

The study has some significant implications for firms in order to enhance their performance. Firms should aim at non-family directors on the board and should not allow banks to be their major shareholders since both negatively impact the firm' $s$ risk-taking abilities and thereby hampering its performance. Firms should also encourage its directors to have more ownership in its stocks since that would induce them to make decisions catering for their incentives also. Also, a single person should hold both the chairman and chief executive officer since it provides a better decision-making power and the unity of command.

\section{LIMITATIONS}

The code of conduct for the firms in relation to corporate governance has not been applied in true sense by many firms. Company websites do not contain historical reports, and in some cases even the websites do not exist. This hampers the objectives of researchers who are interested in exploring corporate governance and its relationships. At present, data availability is the major hurdle in such projects. Issues like data verification and data authenticity may also be relevant in this context.

\section{FUTURE DIRECTIONS}

Future research should be aimed at exploring more corporate governance variables for their associations with firm risk and firm performance using the dynamic panel estimation techniques. Also, an effort should be made to enhance the 
Alam and Shah

sample size in this regard. Sector-wise analysis may also be done in order to explore the sectorspecific firm risk metrics. Researchers should try to adopt modern econometric techniques in order to establish causality between the corporate governance variables. Future research should also try to incorporate more firms into the analysis so that the issues like selective sampling bias could be catered for; which at present is not possible because of the data unavailability.

\section{REFERENCES}

Aman, H. \& Nguyen, P. (2008). Do stock prices reflect the corporate governance quality of Japanese firms? Journal of the Japanese and International Economies, 22(4): 647662

Anderson, R.C. \& Reeb, D.M. (2003). Founding-family ownership and firm performance: Evidence from the S\&P 500. Journal of Finance, 58(3): 1301-1328.

Arellano, M., \& Bond, S. (1991). Some tests of specification for panel data: Monte Carlo evidence and an application to employment equations. Review of Economic Studies, 58(2): 277-297.

Arellano, M. \& Bover, O. (1995). Another look at the instrumental variable estimation of error-component models. Journal of Econometrics, 68(1): 29-51.

Barca, F. (1995). On corporate governance in Italy: Issues, facts, and agency. Unpublished working paper. Bank of Italy, Rome.

Beck, T., Levine, R. \& Loayza, N. (2000). Finance and the sources of growth. Journal of Financial Economics, 58(1): 261-300.

Belkhir, M. (2009). Board of director's size and performance in banking industry. International Journal of Managerial Finance, 5(2): 201-221.

Bhagat, S. \& Black, B. (2002). The non-correlation between board independence and long term firm performance. Journal of Corporation Law, 27(2): 231-274.

Bhagat, S. \& Bolton, B. (2008). Corporate governance and firm performance. Journal of Corporate Finance, 14(3): 257-273.
Bloom, M. \& Milkovich, G.T. (1998). Relationships among risk, incentive pay, and organizational performance. Academy of Management Journal, 41(3): 283-296.

Chen, C., Guo, W. \& Mande, V. (2003). Managerial ownership and firm valuation: Evidence from Japanese firm. PacificBasin Finance Journal, 11(3): 267-283.

Cheng, S., Evans, J.H. \& Nagarajan, N.J. (2008). Board size and firm performance: The moderating effects of the market for corporate control. Review of Quantitative Finance and Accounting, 31(2): 121-145.

Claessens, S. (2006). Corporate governance and development. The World Bank Research Observer, 21(1): 91-122.

Claessens, S. \& Djankov, S. (1999). Ownership concentration and corporate performance in the Czech Republic. Journal of Comparative Economics, 27(3): 498-513.

Conyon, M.J. \& Peck, S.I. (1998). Board size and corporate performance: Evidence from European countries. European Journal of Finance, 4(3): 291-304.

Cremers, K.J. \& Nair, V. (2005). Governance mechanisms and equity prices. Journal of Finance, 60(6): 2859-2894.

Dar, L.A., Naseem, M.A., Rehman, R. \& Niazi, G.S.K. (2011). Corporate governance and firm performance: A case study of Pakistan oil and gas companies listed in Karachi stock exchange. Global Journal of Management and Business Research, 11(8): 1-10.

Drobetz, W., Schillhofer, A. \& Zimmermann, H. (2003). Corporate governance and expected stock returns: Evidence from Germany. Working Paper, University of Basel.

Eisenberg, T., Sundgren, S. \& Wells, M.T. (1998). Larger board size and decreasing firm value in small firms. Journal of Financial Economics, 48(1): 35-54.

Eling, M. \& Marek, S. (2011). Corporate governance and risk taking: Evidence from the U.K. and German insurance markets. Institute of Insurance Economics, Working Papers on Risk Management and Insurance No. 103.

Erickson, J., Park, Y.W., Reising, J. \& Shin H.H. (2005). Board composition and firm value under concentrated ownership: The Canadian evidence. Pacific-Basin Finance Journal, 13(4): 387-410.

Fama, E.F. (1980). Agency problems and the theory of the firm. Journal of Political Economy, 88(2): 134-145. 
International Journal of Management, Economics and Social Sciences

Fama, F. \& French, K. (1993). Common risk factors in the returns on stocks and bonds. Journal of Financial Economics, 33(1): 3-56.

Finkelstein, S. \& D' Aveni, R. (1994). CEO duality as a double-edged sword: How boards of directors balance entrenchment avoidance and unity of command. Academy of Management Journal, 37(5): 1079-1108.

Griliches, Z. \& Hausman, J.A. (1986). Errors in variables in panel data. Journal of Econometrics, 31(1): 93-118.

Guest, P.M. (2009). The impact of board size on firm performance: Evidence from the UK. The European Journal of Finance, 15(4): 385-404.

Haleblian, J. \& Finkelstein, S. (1993). Top management team size, CEO dominance and firm performance: The moderating roles of environmental turbulence and discretion. Academy of Management Journal, 36(4): 844863.

Hirshleifer, D. \& Thakor, A. (1992). Managerial conservatism, project choice, and debt. The Review of Financial Studies, 5(3): $437-470$

Holtz-Eakin, D., Newey, W. \& Rosen, H.S. (1988). Estimating vector autoregressions with panel data. Econometrica, 56(6): 1371-1395.

Hsu, H-E. (2008). Audit committees in U.S. entrepreneurial firms. Journal of American Academy of Business, 13(1): $121-128$

Hutchinson, M. (2001). Firm risk, corporate governance and firm performance, in Governance and corporate social responsibility in the new millennium: Governance and Social Responsibility Conference: proceedings of the 2001 Conference, 26th \& 27th November 2001, School of Accounting and Finance, Deakin University, Burwood, Vic., pp. 1-16.

Hutchinson, M. \& Gul, F.A. (2004). Investment opportunity set, corporate governance practices and firm performance. Journal of Corporate Finance, 10(4): 595-614.

Ibrahim, Q., Rehman, R. \& Raoof, A. (2010). Role of corporate governance in firm performance: A comparative study between chemical and pharmaceutical sectors of Pakistan. International Research Journal of Finance and Economics, 50: 7-16.

Javid, A.Y. \& labal, R. (2008). Ownership concentration, corporate governance and firm performance: Evidence from Pakistan. The Pakistan Development Review, 47(4): 643659
Jensen, M.C. \& Meckling, W.H. (1976). Theory of the firm: Managerial behaviour, agency costs and ownership structure. Journal of Financial Economics, 3(4): 305-360.

John, K., Litov, L. \& Yeung, B. (2008). Corporate governance and risk-taking. Journal of Finance, 63(4): 1679-1728.

Khan, A. \& Awan, S.H. (2012). Effect of board composition on firm's performance: A case of Pakistani listed companies. Interdisciplinary Journal of Contemporary Research in Business, 3(10): 853-863.

Kyereboah-Coleman, A. \& Biepke, N. (2006). The link between corporate governance and performance of the non-traditional export sector: Evidence from Ghana. Corporate Governance: International Journal of Business in Society, 6(5): 609-623.

Lasfer, M.A. (2004). On the monitoring role of the board of directors: The case of the adoption of Cadbury recommendations in the UK. Advances in Financial Economics, 9: 287-326

Mak, Y.T. \& Kusnadi, Y. (2005). Size really matters: Further evidence on the negative relationship between board size and firm value. Pacific-Basin Finance Journal, 13(3): 301318.

Maury, B. (2006). Family ownership and firm performance: Empirical evidence from Western European corporations. Journal of Corporate Finance, 12(2): 321-341.

McConnell, J.J. \& Servaes, H. (1990). Additional evidence on equity ownership and corporate value. Journal of Financial Economics, 27(2): 595-612.

Morck, R., Nakamura, M. \& Shivdasani, A. (2000). Banks, ownership structure, and firm value in Japan. Journal of Business, 73(4): 539-567.

Nguyen, P. (2011). Corporate governance and risk-taking: Evidence from Japanese firms. Pacific-Basin Finance Journal, 19(3): 278-297.

O'Connor, T. (2012). Investability, corporate governance and firm value. Research in International Business and Finance, 26(1): 120-136.

Rabelo, F. \& Vasconcelos, F. (2002). Corporate governance in Brazil. Journal of Business Ethics. 37(3): 321-335.

Saito, T. (2008). Family firms and firm performance: Evidence from Japan. Journal of the Japanese and International Economies, 22(4): 620-646.

Shah, S.Z.A., Butt, S.A. \& Saeed, M.M. (2011). Ownership structure and performance of firms: Empirical evidence 
Alam and Shah

from an emerging market. African Journal of Business

Management, 5(2): 515-523.

Singh, H. \& Harianto, F. (1989). Management-board relationships, takeover risk and adoption of golden parachutes. Academy of Management Journal, 32(1): 724.

Wahla, K., Shah, S.Z.A. \& Hussain, Z. (2012). Impact of ownership structure on firm performance: Evidence from non-financial listed companies at Karachi stock exchange. International Research Journal of Finance and Economics, 84: $6-13$

Weinstein, D. \& Yafeh, Y. (1998). On the costs of a bank centered financial system: Evidence from the changing main bank relations in Japan. Journal of Finance, 53(2): 635-672.

Westphal, J.D. \& Zajac, E.J. (1995). Who shall govern? CEO/board power, demographic similarity, and new director selection. Administrative Science Quarterly, 40(1): 60-83.

Wintoki, M.B., Linck, J.S. \& Netter, J.M. (2012). Endogeneity and the dynamics of internal corporate governance. Journal of Financial Economics, 105(3): 581-606.

Wright, P., Ferris, S.P., Sarin, A. \& Awasthi, V. (1996). Impact of corporate insider, blockholder and institutional equity ownership on firm risk taking. Academy of Management Journal, 39(2): 441-463.

Yermack, D. (1996). Higher market valuation of companies with a small board of directors. Journal of Financial Economics, 40(1): 185-211.

Yasser, Q.R., Entebang, H. \& Mansor, S.A. (2011). Corporate governance and firm performance in Pakistan: The case of Karachi stock exchange (KSE)-30. Journal of Economics and International Finance, 3(8): 482-491. 


\begin{tabular}{|c|c|c|c|c|c|}
\hline Paper & Sample (firms) & Period & Governance Variables Used & Methodology & Estimated Relationship \\
\hline \multicolumn{6}{|c|}{ Panel A: Relationship between Corporate Governance and Firm Risk } \\
\hline $\begin{array}{l}\text { Wright, Ferris, Sarin and } \\
\text { Awasthi (1996) }\end{array}$ & $\begin{array}{l}358(1986) \\
514(1992)\end{array}$ & 1986,1992 & $\begin{array}{l}\text { Managerial Ownership (MO), } \\
\text { Block-holder Ownership (BO), } \\
\text { Institutional Ownership (IO) }\end{array}$ & OLS & $\begin{array}{l}\text { IO and Risk: Positive } \\
\text { MO and Risk: Negative }\end{array}$ \\
\hline $\begin{array}{l}\text { Weinstein and Yafeh } \\
\text { (1998) }\end{array}$ & $\begin{array}{c}700 \\
\text { (Japan) }\end{array}$ & $1977-1986$ & Bank Control (BC) & OLS & BC and Risk: Negative \\
\hline Hutchinson (2001) & $\begin{array}{c}282 \\
\text { (Australia) }\end{array}$ & 1998/99 & $\begin{array}{c}\text { Executive Remuneration (ER), } \\
\text { Managerial Ownership (MO), Board } \\
\text { Composition (BC) }\end{array}$ & OLS & $\begin{array}{l}\text { MO and Risk: Positive } \\
\text { ER and Risk: Positive } \\
\text { ER and Performance: Positive }\end{array}$ \\
\hline $\begin{array}{l}\text { John, Litov and Yeung } \\
\text { (2008) }\end{array}$ & $\begin{array}{c}6024 \\
(39 \text { Countries) }\end{array}$ & $1992-2002$ & $\begin{array}{l}\text { Investor Protection (IP), Stakeholder } \\
\text { Influence (SI) }\end{array}$ & OLS, 2SLS & IP and Risk: Positive \\
\hline Eling and Marek (2011) & $\begin{array}{c}35 \\
\text { (UK and Germany) }\end{array}$ & $1997-2010$ & $\begin{array}{c}\text { Board Compensation (BC), Board } \\
\text { Monitoring (BM), Number of } \\
\text { Block-holders (BH) }\end{array}$ & SEM & $\begin{array}{l}\text { BC and Risk: Negative } \\
\text { BM and Risk: Negative } \\
\text { BH and Risk: Negative }\end{array}$ \\
\hline Nguyen (2011) & $\begin{array}{c}1252 \\
\text { (Japan) }\end{array}$ & $1996-2003$ & $\begin{array}{c}\text { Bank Control (BC), Family Control } \\
\text { (FC), Ownership Concentration } \\
\text { (OC) }\end{array}$ & OLS & $\begin{array}{l}\text { FC and Risk: Positive } \\
\text { BC and Risk: Negative } \\
\text { OC and Risk: Positive }\end{array}$ \\
\hline
\end{tabular}




\section{Alam and Shah}

Panel B: Relationship between Corporate Governance and Firm Performance (or Firm Value)

\begin{tabular}{|c|c|c|c|c|c|}
\hline $\begin{array}{l}\text { Claessens and Djankov } \\
\text { (1999) }\end{array}$ & $\begin{array}{c}706 \\
\text { (Czech Republic) }\end{array}$ & 1992-1997 & Ownership Concentration & OLS, RE & OC and Performance: Positive \\
\hline $\begin{array}{l}\text { Morck, Nakamura and } \\
\text { Shivdasani (2000) }\end{array}$ & $\begin{array}{c}373 \\
\text { (Japan) }\end{array}$ & & $\begin{array}{c}\text { Bank Ownership (BO), Managerial } \\
\text { Ownership (MO) }\end{array}$ & OLS & $\begin{array}{l}\text { BO and Value: Negative } \\
\text { MO and Value: Positive }\end{array}$ \\
\hline $\begin{array}{l}\text { Anderson and Reeb } \\
\text { (2003) }\end{array}$ & $\begin{array}{c}403 \\
\text { (US) }\end{array}$ & 1992-1999 & $\begin{array}{l}\text { Family Ownership (FO), CEO } \\
\text { Compensation (CC), Directors' } \\
\text { Ownership (DO), Percentage of } \\
\text { Outside Directors (POD) }\end{array}$ & OLS, RE & FO and Performance: Positive \\
\hline Maury (2006) & $\begin{array}{c}1672 \\
\text { (Western Europe) }\end{array}$ & 1996/97/98/99 & Family Control (FC) & $\begin{array}{c}\text { OLS, Heckman (1979) } \\
\text { Two-Step Treatment } \\
\text { Effects Model }\end{array}$ & FC and Performance: Positive \\
\hline Saito (2008) & $\begin{array}{c}1818 \\
\text { (Japan) }\end{array}$ & 1990-1998 & Family Control (FC) & OLS & FC and Performance: Positive \\
\hline Aman and Nguyen (2008) & (Japan) & $2000-2005$ & $\begin{array}{l}\text { Board Characteristics, Ownership } \\
\text { Structure, Quality of Disclosure and } \\
\text { Respect for Investors' Interests }\end{array}$ & OLS & $\begin{array}{l}\text { Corporate Governance and } \\
\text { Performance: Negative }\end{array}$ \\
\hline O’Connor (2012) & $\begin{array}{c}251 \\
(20 \text { countries })\end{array}$ & $1980-2000$ & $\begin{array}{l}\text { Strength of Corporate Governance } \\
\text { (CG) }\end{array}$ & OLS, RE, FEVD & CG and Value: Positive \\
\hline $\begin{array}{l}\text { Wintoki, Linck, } \\
\text { Netter (2012) }\end{array}$ & 6000 & $1991-2003$ & $\begin{array}{c}\text { Board Size (BS), Board } \\
\text { Composition (BC) and Board } \\
\text { Leadership (BL) }\end{array}$ & $\begin{array}{l}\text { OLS, FE, DOLS, } \\
\text { System GMM }\end{array}$ & $\begin{array}{c}\text { No relationship between Board } \\
\text { Structure variables and } \\
\text { Performance using System GMM }\end{array}$ \\
\hline
\end{tabular}


International Journal of Management, Economics and Social Sciences

Panel C: Relationship between Corporate Governance and Firm Performance in Pakistan

\begin{tabular}{|c|c|c|c|c|c|}
\hline $\begin{array}{l}\text { Javid and Iqbal } \\
\qquad(2008)\end{array}$ & $\begin{array}{c}60 \\
\text { (Pakistan) }\end{array}$ & $2003-2008$ & $\begin{array}{l}\text { Ownership Concentration (OC), } \\
\text { Managerial Shareholding (MS), }\end{array}$ & OLS & $\begin{array}{l}\text { OC and Performance: Positive } \\
\text { MS and Performance: Positive }\end{array}$ \\
\hline $\begin{array}{l}\text { Ibrahim, Rehman and } \\
\text { Raoof (2010) }\end{array}$ & $\begin{array}{c}10 \\
\text { (Pakistan) }\end{array}$ & $2005-2009$ & $\begin{array}{c}\text { Board Size (BS), Board } \\
\text { Independence (BI), Ownership } \\
\text { Concentration (OC) }\end{array}$ & OLS & BI and Performance: Positive \\
\hline $\begin{array}{l}\text { Shah, Butt and Saeed } \\
\qquad(2011)\end{array}$ & $\begin{array}{c}67 \\
\text { (Pakistan) }\end{array}$ & 2005 & Ownership Structure (OS) & Cluster Analysis & OS and Performance: Negative \\
\hline $\begin{array}{l}\text { Yasser, Entebang and } \\
\text { Mansor (2011) }\end{array}$ & $\begin{array}{c}30 \\
\text { (Pakistan) }\end{array}$ & $2008-2009$ & $\begin{array}{c}\text { Board Size (BS), Board } \\
\text { Composition (BC), CEO/chairman } \\
\text { duality (CD), Audit Committee } \\
\text { (AC) }\end{array}$ & OLS & $\begin{array}{l}\text { BS and Performance: Positive } \\
\text { BC and Performance: Positive } \\
\text { AC and Performance: Positive }\end{array}$ \\
\hline $\begin{array}{l}\text { Dar, Naseem, } \\
\text { Rehman and Niazi } \\
\text { (2011) }\end{array}$ & $\begin{array}{c}12 \\
\text { (Pakistan) }\end{array}$ & $2004-2010$ & $\begin{array}{l}\text { Board Size (BS), Audit Committee } \\
\text { (AC), CEO Status (CS) }\end{array}$ & OLS & $\begin{array}{l}\text { BS and Performance: Positive } \\
\text { AC and Performance: Negative } \\
\text { CS and Performance: Negative }\end{array}$ \\
\hline $\begin{array}{l}\text { Khan and Awan } \\
\text { (2012) }\end{array}$ & $\begin{array}{c}91 \\
\text { (Pakistan) }\end{array}$ & 2010 & Board Composition (BC) & $t$-tests & BC and Performance: Positive \\
\hline $\begin{array}{l}\text { Wahla, Shah and } \\
\text { Hussain (2012) }\end{array}$ & $\begin{array}{c}61 \\
\text { (Pakistan) }\end{array}$ & $2008-2010$ & $\begin{array}{l}\text { Managerial Ownership (MO), } \\
\text { Ownership Concentration (OC) }\end{array}$ & $\mathrm{CE}$ & MO and Performance: Negative \\
\hline
\end{tabular}


Appendix-11

\begin{tabular}{|c|c|c|c|c|c|c|c|c|c|c|c|c|c|c|}
\hline & IR & BO & FO & MO & BH & BI & BS & DUALITY & ACI & FS & FL & GO & FP & CI \\
\hline IR & 1 & & & & & & & & & & & & & \\
\hline BO & $-0.11^{* * *}$ & 1 & & & & & & & & & & & & \\
\hline FO & $0.12^{* * *}$ & 0.02 & 1 & & & & & & & & & & & \\
\hline MO & $0.11^{* * *}$ & -0.02 & $0.46^{* * *}$ & 1 & & & & & & & & & & \\
\hline BH & -0.04 & $-0.08^{*}$ & $-0.35^{* * *}$ & $-0.14^{* * *}$ & 1 & & & & & & & & & \\
\hline BI & 0.01 & 0.06 & $-0.09^{* *}$ & $-0.37^{* * *}$ & 0.04 & 1 & & & & & & & & \\
\hline BS & -0.05 & $0.10^{* * *}$ & $-0.18^{* * *}$ & $-0.23^{* * *}$ & $-0.13^{* * *}$ & $0.33^{* * *}$ & 1 & & & & & & & \\
\hline DUALITY & $0.19^{* * *}$ & 0.02 & $-0.07^{*}$ & $0.10^{* *}$ & $0.24^{* * *}$ & $-0.21^{* * *}$ & $-0.17^{* * *}$ & 1 & & & & & & \\
\hline ACI & -0.02 & 0.02 & $-0.21^{* * *}$ & $-0.35^{* * *}$ & $0.15^{* * *}$ & $0.74^{* * *}$ & $0.30^{* * *}$ & $-0.09^{* *}$ & 1 & & & & & \\
\hline FS & $-0.24^{* * *}$ & $0.18^{* * *}$ & $-0.26^{* * *}$ & $-0.23^{* * *}$ & $0.07^{*}$ & $0.16^{* * *}$ & $0.35^{* * *}$ & $-0.07^{*}$ & $0.23^{* * *}$ & 1 & & & & \\
\hline FL & -0.01 & -0.04 & $-0.11^{* * *}$ & $-0.12^{* * *}$ & $0.11^{* * *}$ & $-0.13^{* * *}$ & -0.05 & $0.10^{* *}$ & $-0.12^{* * *}$ & $-0.15^{* * *}$ & 1 & & & \\
\hline GO & $0.10^{* * *}$ & $0.09^{* *}$ & $0.22^{* * *}$ & $0.14^{* * *}$ & $-0.19^{* * *}$ & $-0.11^{* * *}$ & $-0.13^{* * *}$ & 0.02 & $-0.171^{* * *}$ & $-0.14^{* * *}$ & $0.07^{*}$ & 1 & & \\
\hline FP & $-0.09^{* *}$ & $-0.11^{* * *}$ & $-0.21^{* * *}$ & $-0.24^{* * *}$ & $0.16^{* * *}$ & $0.15^{* * *}$ & $0.10^{* * *}$ & -0.02 & $0.12^{* * *}$ & $0.10^{* * *}$ & $0.29^{* * *}$ & $-0.39^{* * *}$ & 1 & \\
\hline CI & $0.07 *$ & -0.02 & $0.08^{*}$ & $0.29^{* * *}$ & $-0.19^{* * *}$ & -0.01 & -0.01 & 0.02 & -0.03 & $0.14^{* * *}$ & $-0.21^{* * *}$ & 0.004 & $-0.28^{* * *}$ & 1 \\
\hline
\end{tabular}

Note: IR represents the idiosyncratic (or firm-specific) risk. BO and FO refer to bank ownership (a dummy variable having value 1 for a firm having a bank as its majority shareholder (more than $50 \%$ shareholding) and 0 otherwise) and family ownership (a dummy variable having value 1 for a family firm and 0 otherwise) respectively. MO and BH correspond to managerial ownership (the ratio of shares held by board of directors and the total number of shares) and block holders (the ratio of shares owned by top five shareholders and the total number of shares) respectively. BI refers to board independence which is the ratio of non-executive directors (externa bord meme to the total number of me dit ( ( and the ta urn on assets (ROA) which is the ratio of operating profits to total assets. CI, capital intensity is represented by the ratio of fixed to total assets. $* * *, * *, *$ represent significance at $1 \%, 5 \%$ and $10 \%$ levels respectively. 
Appendix-III

\begin{tabular}{|c|c|c|}
\hline Dependent Variable: Firm Risk & Pooled OLS & Random Effects \\
\hline Bank Ownership & $-0.019(-2.37)^{* *}$ & $-0.018(-1.89)^{*}$ \\
\hline Family Ownership & $0.006(1.25)$ & $0.003(0.30)$ \\
\hline Managerial Ownership & $0.00003(0.29)$ & $0.0003(1.57)$ \\
\hline Block holders & $-0.00005(-0.39)$ & $-0.0004(-1.98)^{* *}$ \\
\hline Board Independence & $0.025(1.74)^{*}$ & $0.011(0.59)$ \\
\hline Board Size & $0.019(1.51)$ & $0.012(0.65)$ \\
\hline Chairman/CEO Duality & $0.028(5.38)^{* * *}$ & $0.020(2.50)^{* *}$ \\
\hline Audit Committee Independence & $-0.002(-0.15)$ & $0.014(0.83)$ \\
\hline Firm Size & $-0.008(-5.24)^{* * *}$ & $-0.001(-0.67)$ \\
\hline Firm Leverage & $-0.00003(-0.50)$ & $0.0002(3.31)^{* * *}$ \\
\hline Growth Opportunities & $0.004(1.61)$ & $0.005(2.71)^{* * *}$ \\
\hline Firm Profitability & $-0.00008(-0.44)$ & $0.00004(0.22)$ \\
\hline Capital Intensity & $0.0002(1.76)^{*}$ & $0.0001(1.01)$ \\
\hline$R^{2}$ & 0.13 & 0.07 \\
\hline
\end{tabular}

Notes:

- $t$-statistics are reported in parentheses.

$\stackrel{* * * * * *}{*}$ represent significance at $1 \%, 5 \%$ and $10 \%$ levels respectively.

Table 8. Impact of Corporate Governance on Firm Risk (Static Model 